\title{
Local cellular immune response in the acute phase of gastritis in mice induced chemically and by Helicobacter pylori
}

\author{
N. E. M. VAN DOORN, E. P. VAN REES*, F. NAMAVAR and J. DE GRAAFF† \\ Departments of Medical Microbiology and ${ }^{*}$ Cell Biology/Immunology, Faculty of Medicine, Vrije Universiteit \\ and TOral Microbiology, ACTA, Amsterdam, The Netherlands
}

\begin{abstract}
Gastritis was induced in mice by oral administration of acetic acid $5 \%$, a $\operatorname{cag} A$ positive Helicobacter pylori strain, or both. The induction of a mild gastritis by acetic acid before inoculation with $\boldsymbol{H}$. pylori resulted in a slight but not significantly decreased colonisation rate. To study the initial stage of inflammation, the presence of gastric lymphoid and non-lymphoid cells was studied by immunohistochemistry during the first 2 weeks after induction of gastritis. Treatment with acetic acid alone or in combination with $\mathrm{H}$. pylori resulted in an increase in the number of neutrophils in the mucosa and submucosa, without evident epithelial damage. The influx of neutrophils was most prominent in the mice that received a combined treatment of acetic acid and $\boldsymbol{H}$. pylori. Macrophages were also increased in both acetic acid and acetic acid plus $H$. pylori-treated groups, although a different kinetic pattern was present in these groups. In mice infected with $\mathrm{H}$. pylori alone, only a slight but not significant increase in neutrophils and macrophages was observed. The early presence of lymphoid aggregates in the gastric mucosa of mice in which colonisation was shown with $\boldsymbol{H}$. pylori was remarkable. This phenomenon was not seen in control mice, in mice that received acetic acid alone or when colonisation was not shown. These data suggest that gastritis induced by a chemical agent such as acetic acid occurs by a different mechanism than gastritis induced by $H$. pylori and that the continued presence of $\boldsymbol{H}$. pylori is required for local lymphocyte activation.
\end{abstract}

\section{Introduction}

Helicobacter pylori is now accepted to be the causative agent of gastritis and peptic ulcer disease. It is a spiralshaped, flagellate, gram-negative bacterium that is uniquely adapted to survive in the gastric environment of man. It is not invasive but colonises the mucus layer [1]. A potent urease enzyme, flagella and adhesin proteins have been shown to be important virulence factors $[2-5]$.

Prolonged colonisation with $H$. pylori induces a chronic inflammatory response, which is characterised by an increase in the number of lymphocytes, plasma cells and polymorphonuclear granulocytes in the lamina propria [6]. Nevertheless, the infection is not limited by this response and this ongoing state of immune activation may lead to atrophic mucosa and

Received 11 Aug. 1997; revised version accepted 14 Jan. 1998.

Corresponding author: Dr N. E. M. van Doorn. intestinal metaplasia. Eventually this can result in the formation of gastric and duodenal ulcers and even in gastric carcinoma [7].

The pattern of disease and its severity seem to be correlated with bacterial genotype. Strains that express a cytotoxin-associated gene $(\operatorname{cag} A)$, combined with a cytotoxin which is regulated by the cytotoxin gene $(v a c A)$ are more often detected in patients with duodenal ulcer disease than in patients with other types of gastric dyspepsia [8].

Several experimental animal models have been described for the study of the pathogenesis of gastric inflammation after infection with $H$. pylori, or for investigation of the virulence factors described above. In some of these studies, species related to $H$. pylori, such as $H$. felis and $H$. mustelae, have been used [912], but there are genotypic differences between $H$. pylori and $H$. felis or $H$. mustelae, as the latter two produce no cytotoxin. Several reports have described chronic inflammation due to infection with fresh clinical isolates of $H$. pylori in immunocompetent 
mice [13-15]. Many data have been obtained from these studies, but the initial effects of infection with H. pylori are still unknown.

Just as in animal models, so in human disease only limited data are available on the acute phase of $H$. pylori infection. In human subjects, only two cases of acute gastritis have been described. Two healthy volunteers who ingested a $H$. pylori culture developed acute symptoms of abdominal disorder and, histologically, an increase in the number of polymorphonuclear granulocytes was found in the lamina propria of gastric tissue $[16,17]$.

There are data to indicate that the state or condition of the gastric mucosa is important for the outcome of $H$. pylori infection. Enhanced colonisation with $H$. pylori was described in the case of pre-existent indomethacin-induced ulcers in gerbils [18]. It has also been shown that in patients who take non-steroidal antiinflammatory drugs, mucosal ulceration is more likely to develop when $H$. pylori is present [19]. To take these data into account, three different approaches were used to compare the involvement of immunologically active cells in a non-specific acute gastritis with their role in a specific $H$. pylori gastritis. Gastric inflammation in immunocompetent mice was studied after oral administration of either acetic acid or $H$. pylori, to determine the initial events in chemically and $H$. pylori-induced gastritis. A combined treatment of acetic acid and H. pylori was given to determine whether a pre-existing gastritis influenced the course of $H$. pylori infection.

\section{Materials and methods}

\section{Animals}

Female 6-9-week-old Swiss (SPF) mice (Harlan CPB, Zeist, The Netherlands) were housed in conventional conditions in our animal facilities. The mice had free access to commercial food and water.

\section{H. pylori strain}

H. pylori strain 3B3 was isolated in this department from the oral cavity of a patient with gastritis [20] and identified by Gram's stain, positive oxidase, catalase and urease reactions, and 16S RNA PCR analysis. DNA of strain 3B3 was isolated [21] and PCR analysis [22] showed that this strain was $\operatorname{cag} A$ positive.

H. pylori was grown in Brucella Broth (Difco, Detroit, USA) supplemented with fetal calf serum (Gibco BRL, Grand Island, NY, USA) $5 \%$ at $37^{\circ} \mathrm{C}$ in microaerobic conditions and with agitation. After 2 days the bacteria were harvested by centrifugation $(10 \mathrm{~min}$, $1500 \mathrm{~g}$ ), washed in sterile phosphate-buffered saline (PBS) and suspended in PBS at a concentration of $5 \times 10^{9} \mathrm{cfu} / \mathrm{ml}$.

\section{Experimental design}

The protocol described below was approved by the animal care committee of the Vrije Universiteit of Amsterdam. The mice were divided into four groups and were fasted overnight before treatment. In group 1 $(\mathrm{n}=15)$ gastritis was induced chemically on day 1 by oral administration of $0.2 \mathrm{ml}$ of acetic acid $5 \%(\mathrm{pH} 2)$ with a feeding needle. On days 2 and 4 the mice received $0.2 \mathrm{ml}$ of PBS. Group $2(\mathrm{n}=30)$ received $0.2 \mathrm{ml}$ of acetic acid $5 \%$ on day 1 and $0.2 \mathrm{ml}$ of $H$. pylori suspension $\left(1 \times 10^{9} \mathrm{cfu}\right)$ on days 2 and 4 . Group $3(\mathrm{n}=18)$ received no acetic acid, but received $0.2 \mathrm{ml}$ of PBS on day 1 and $0.2 \mathrm{ml}$ of $H$. pylori suspension on days 2 and 4 . Group $4(n=12)$ consisted of untreated healthy mice as controls. After fasting overnight mice were killed on day 5,8 or 12 by cervical dislocation under ether anaesthesia. The number of mice that were killed at each time point in groups 1,2 and 3 was 5,10 and 6 , respectively. The stomachs were removed and inspected for macroscopic lesions. One half of the stomach was streaked on freshly prepared Dent plates [23] for culture, the other half was frozen immediately in liquid nitrogen for immunohistochemistry. Cultures were incubated micro-aerobically for 5 days. H. pylori colonies were identified by Gram's stain and by positive urease, oxidase and catalase reactions. If any $H$. pylori colonies were detected in culture, the mice were defined as positive, regardless of the number of colonies present. The stomachs of the control mice in group 4 were used for immunohistochemistry only.

\section{Immunohistochemistry}

Cryostat sections $(8 \mu \mathrm{m})$ were picked up on slides and air-dried. After fixation for $10 \mathrm{~min}$ in pure acetone, a two-step immunoperoxidase method was used. Slides were incubated horizontally for $60 \mathrm{~min}$ at room temperature with a solution of the first step monoclonal antibody (MAb; $10-20 \mu \mathrm{g} / \mathrm{ml}$ ) in $0.01 \mathrm{M} \mathrm{PBS} \mathrm{(pH}$ 7.4), with bovine serum albumin (BSA) $0.5 \%$. The slides were washed three times in PBS and then incubated with the appropriate peroxidase-conjugated antiserum (Dako, Glostrup, Denmark), diluted 1 in 100 in PBS with BSA $0.5 \%$ and normal mouse serum $10 \%$ for $30 \mathrm{~min}$. After rinsing in PBS $(3 \times 10 \mathrm{~min})$, sections were stained for peroxidase activity with 3,3'-diaminobenzidine-tetra-hydrochloride (Sigma, St Louis, MO, USA) in $0.05 \mathrm{M}$ Tris- $\mathrm{HCl}(\mathrm{pH} 7.6)$ containing freshly added $\mathrm{H}_{2} \mathrm{O}_{2} \quad 0.01 \%$ [24]. After the slides had been washed in PBS, they were lightly counter-stained with haematoxylin, dehydrated and mounted in Entellan (Merck, Darmstadt, Germany). Control slides were incubated in PBS with BSA $0.5 \%$ in the first step, instead of the first specific antibody, and examined for non-specific staining. Sections of the spleen were included on every slide as a positive control. Consecutive sections were stained with MAbs RA3-6B2, 59AD-22, MOMA-2, M5.114 and NLDC-145. RA3-6B2 recognises $\mathrm{B} 220$ on $\mathrm{B}$ cells [25], 59-AD-22 recognises Thy-1 on T cells [26], MOMA-2 is a pan-macrophage 
marker [27], M5.114 recognises MHC class II [28] and NLDC-145 recognises dendritic cells [29]. These MAbs were raised in this laboratory. Neutrophils were detected by endogenous peroxidase staining.

\section{Quantification and statistical analysis}

Fisher's test was used to compare the proportion of infected mice in groups 2 and 3 (Table 1). The number of neutrophils present in the stomach was quantified by counting eight microscopic fields $(\times 200)$. Selection of microscopic fields was done by random assignment in three sections. Numbers of macrophages were increased in oedematous areas and six microscopic fields in these areas $(\times 400)$ were counted. When no oedematous areas were present, fields were chosen by random assignment. Positive cells could be discriminated from the homogeneous relatively colourless background. All data are expressed as median and range. Statistical significance of differences was evaluated with the non-parametric Mann-Whitney $U$ test. Statistical significance was defined as $\mathrm{p}<0.05$.

\section{Results}

Colonisation of the mouse stomach with $H$. pylori

As expected, no $H$. pylori could be detected after oral treatment with acetic acid (Table 1). After administration of a combination of acetic acid and $H$. pylori (group 2) the stomachs of 5 of 10 mice were positive for $H$. pylori by culture on day 5 . On day 12 the number of $H$. pylori-positive mice decreased to 2 of 10 animals. In group 3, which received no treatment with acetic acid preceding inoculation with $H$. pylori, on day 5 all mice were positive for $H$. pylori and cultures from four of six mice still were positive on day 12 after initial inoculation.

\section{General observations}

Except for the control group, slight hyperaemia was observed in several animals of all groups, but no major macroscopical damage was found in any of these groups. Microscopically, no lesions could be found in the epithelial cells and gland architecture appeared to be normal. However, oedematous areas were found at all time points in both acetic acid- and acetic acid plus
H. pylori-treated mice. In mice inoculated with $H$. pylori alone, oedema was observed only on days 8 and 12. The oedematous areas were found between mucosa and submucosa in the glandular and non-glandular parts of the stomach (Fig. 1).

\section{Immunohistochemistry}

On day 5 a significant increase in neutrophils was observed in the subglandular region of the stomachs of mice treated with acetic acid and acetic acid plus $H$. pylori, as compared with untreated healthy control mice (Fig. 2). On days 8 and 12 the number of neutrophils was still increased in mice treated with acetic acid plus H. pylori, whereas in the group treated with acetic acid alone the number of neutrophils had decreased to levels not significantly higher than in the controls. In mice inoculated with $H$. pylori alone there was a slight, but not significant increase in neutrophils on days 8 and 12 , and there was a greater variation in the number of neutrophils.

Increased numbers of MOMA-2-positive macrophages were found in oedematous areas of the stomach (Fig. 1). On day 5 an increased number of macrophages was found only in mice treated with acetic acid plus H. pylori (Fig. 3). On day 8 both the acetic acid- and acetic acid plus $H$. pylori-treated mice showed increased numbers of macrophages. In the latter group this number was still increased on day 12 , whereas in the former group the number had declined. The $H$. pylori-treated mice showed no increase in macrophages, but a large variation in the number of macrophages in individual mice was also seen on days 5 and 8 .

In control and acetic acid-treated mice a small number of Thy-1-positive $T$ cells were always present in the lamina propria and at the base of the glands, whereas no B220-positive B cells were detected at any time point.

However, in mice colonised by $H$. pylori in the acetic acid plus $H$. pylori-treated group, small accumulations of lymphoid cells were detected in one or two mice at each time point. Also, lymphocyte accumulation was observed in colonised mice in the H. pylori-treated group, although this was not seen until day 8 . These

Table 1. Number of $H$. pylori-positive mice on days 5,8 and 12 after oral treatment with acetic acid $5 \%$, in combination with $H$. pylori, or with $H$. pylori alone

\begin{tabular}{lllll}
\hline & \multicolumn{4}{c}{ Number of mice colonised $/$ number treated on } \\
\cline { 2 - 5 } Group & day 5 & day 8 & day 12 & Total \\
\hline 1. acetic acid & $0 / 5$ & $0 / 5$ & $0 / 5$ & $0 / 15$ \\
2. acetic acid + H. pylori & $5 / 10$ & $3 / 10$ & $2 / 10$ & $10 / 30$ \\
3. H. pylori & $6 / 6$ & $3 / 6$ & $4 / 6$ & $13 / 18$ \\
\hline The numbers of infected mice in group 2 and 3 do not differ significantly $(\mathrm{p}>0.05$, Fisher's \\
exact test).
\end{tabular}




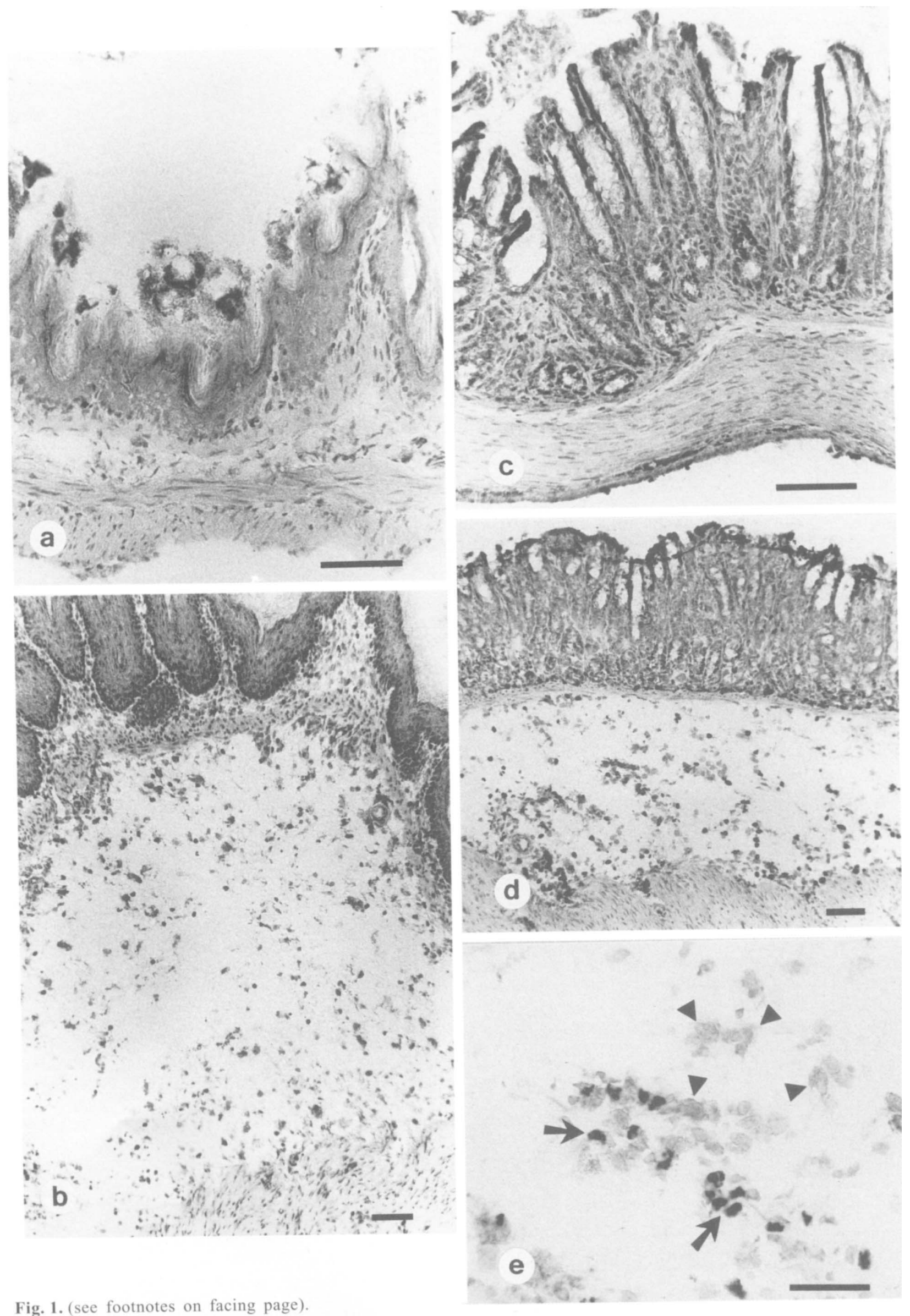




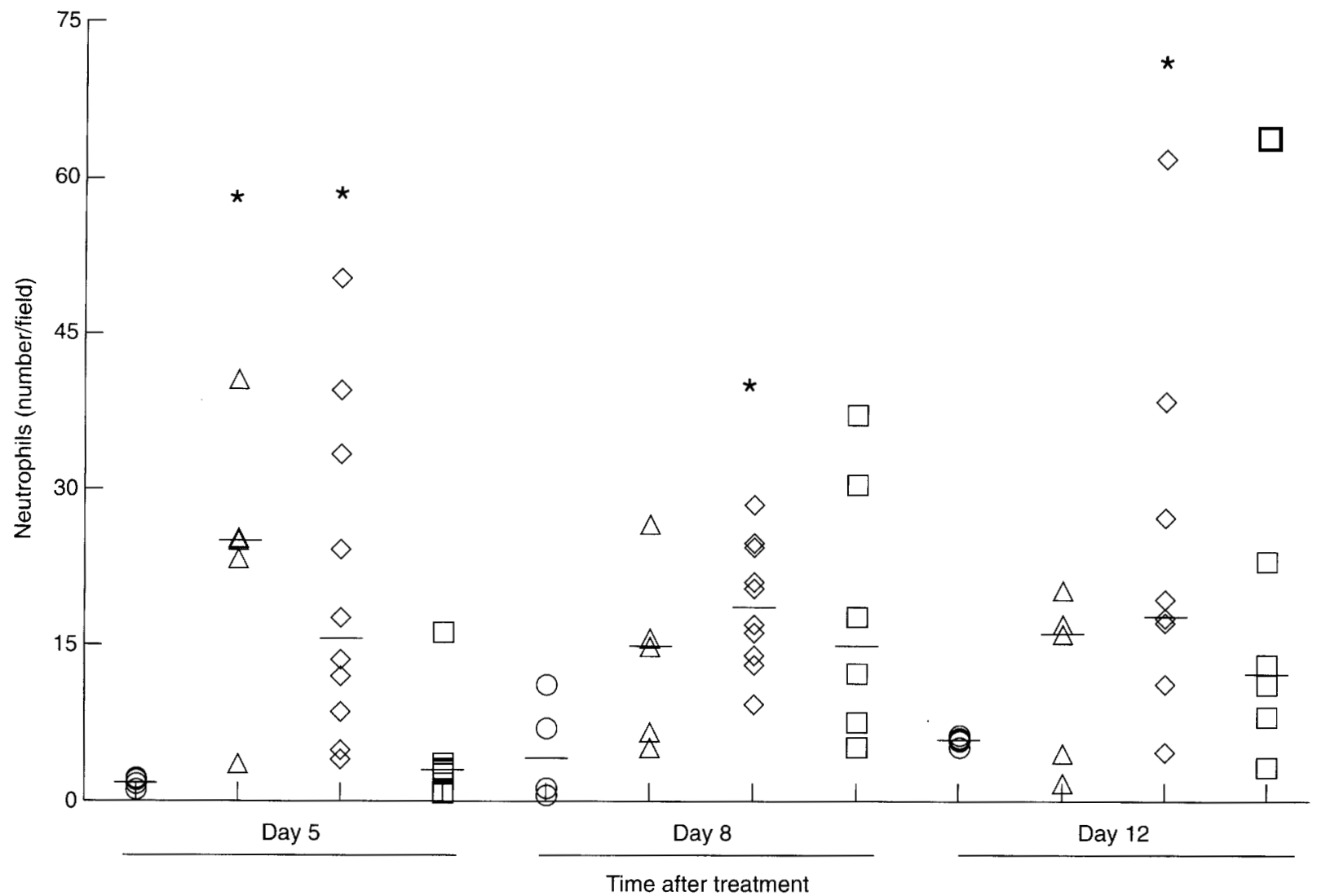

Fig. 2. Number of neutrophils in the glandular part of the stomach per microscopic field $(\times 200)$, on days 5,8 and 12 after oral treatment with: $\triangle$, acetic acid $5 \%$; $\diamond$, acetic acid plus $H$. pylori; $\square, H$. pylori without acetic acid; $\bigcirc$, healthy untreated control mice. Horizontal lines denote median value $\left({ }^{*} \mathrm{p}<0.05\right)$.

accumulations consisted in particular of small B lymphocytes with a few $\mathrm{T}$ lymphocytes intermingled, without plasma cells or macrophages (Fig. 4). The accumulations were located in the corpus part of the stomach and were not found in controls or mice treated with acetic acid alone.

NLDC-145-positive dendritic cells were not present in any part of the stomach of control mice nor in the stomachs of mice treated with acetic acid of $H$. pylori, or both. MHC class II expression was seen on a few epithelial cells on top of the glands and at the base of the glands, but was neither increased nor decreased in any of the groups.

\section{Discussion}

The present study investigated the cellular response of gastric mucosa to a chemical stimulus, i.e., acetic acid, and the response to $H$. pylori infection. In addition, the influence of a chemically induced gastritis on the infection rate by $H$. pylori was studied. Acetic acidinduced gastritis had no significant effect on colonisation by $H$. pylori. This was unexpected, because in gerbils pre-existent ulcers caused by indomethacin correlated with enhanced colonisation by $H$. pylori [19]. Apparently a mild pre-existent inflammation does not lead to increased infection rates after inoculation with $H$. pylori, but rather induces a slight but not significant reduction in colonisation. Administration of acetic acid in the colon of the rat results in short-lived damage to the epithelium and an increased permeability of the mucosa, which is not a result of decrease in $\mathrm{pH}$ [30]. Five days after administration of acetic acid in mice, no epithelial damage was visible in the groups treated with acetic acid and acetic acid plus $H$. pylori, which implies that if any damage had occurred, it was already healed by this time. The lack of epithelial damage after the first week of colonisation with $H$. pylori is consistent with the findings of Cellini et al. [13] and Marchetti et al. [14], who described the

Fig. 1. (a) Non-glandular part of the stomach of a control mouse (bar $=40 \mu \mathrm{m}$; (b) gastric oedema with neutrophils and macrophages on day 5 after oral treatment with acetic acid $5 \%$ (bar $=40 \mu \mathrm{m})$; (c) antrum of a control mouse (bar $=40 \mu \mathrm{m})$; (d) oedema in the antrum at day 8 after inoculation with $H$. pylori without preceding oral acetic acid treatment $(\mathrm{bar}=40 \mu \mathrm{m})$; (e) detail of oedema with neutrophils (arrows) and macrophages (arrowheads) $(\mathrm{bar}=20 \mu \mathrm{m})$. Staining with MAb MOMA-2. Neutrophils are recognised by endogenous peroxidase activity. 


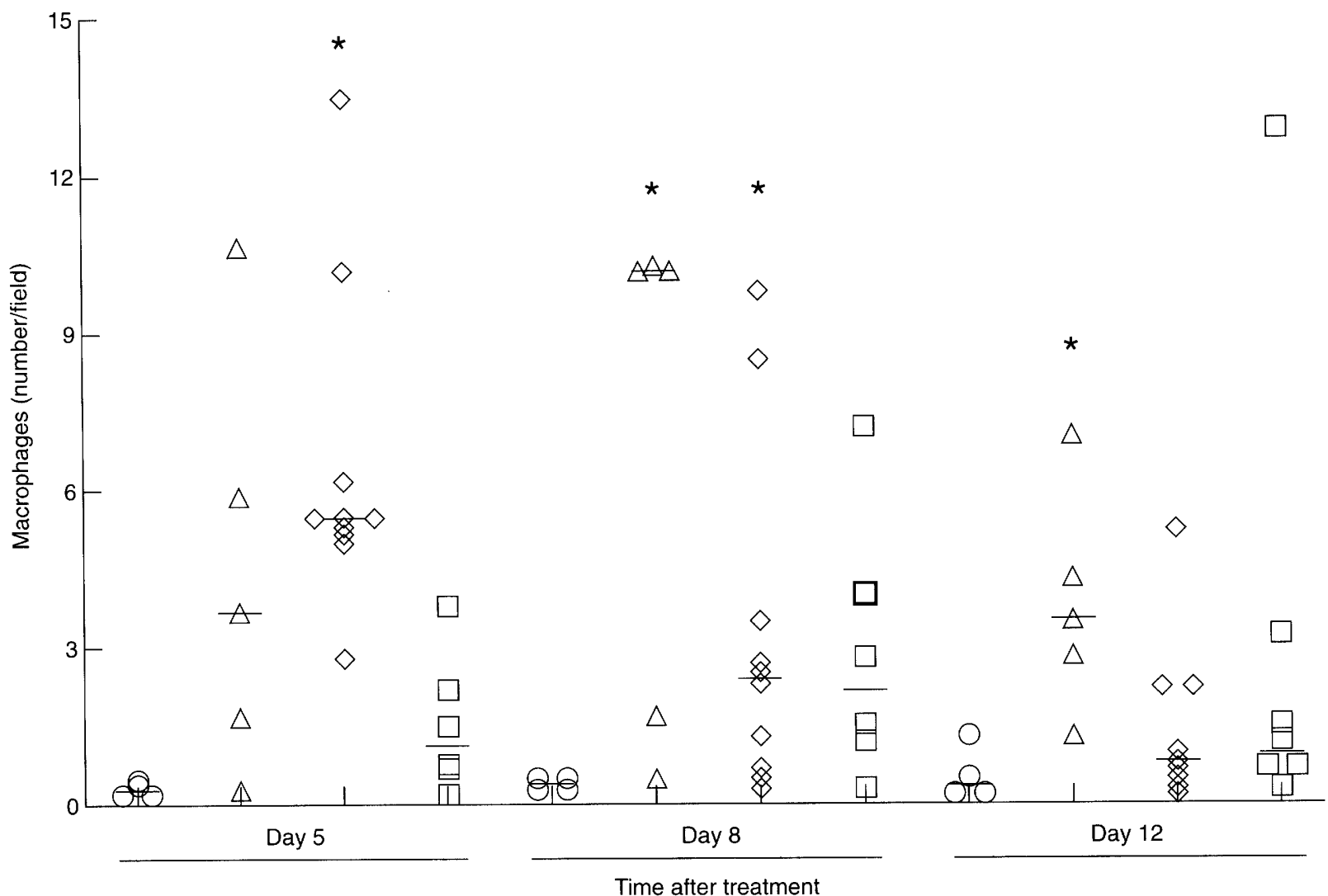

Fig. 3. Macrophages present in the submucosa on days 5, 8 and 12 after treatment with: $\triangle$, acetic acid 5\%; $\diamond$, acetic acid plus $H$. pylori; $\square, H$. pylori without acetic acid; $\bigcirc$, healthy unrelated control mice. Horizontal lines denote median values $\left({ }^{*} \mathrm{p}<0.05\right)$.

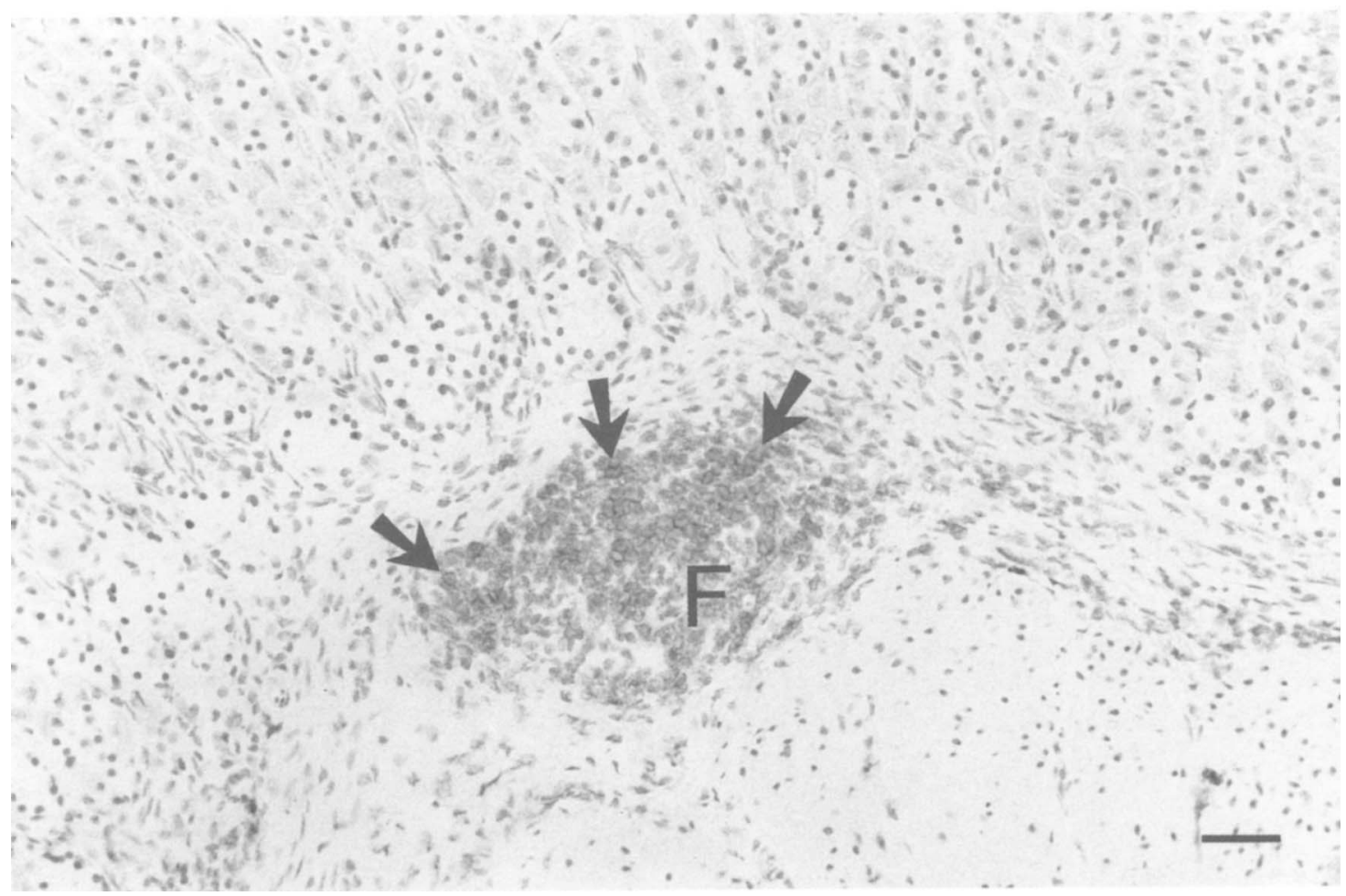

Fig. 4. Small accumulations of lymphocytes (F) after colonisation with $H$. pylori on day 8. Staining with a pan B MAb (bar $=20 \mu \mathrm{m}$ ). 
development of epithelial damage only several weeks after infection. Also in man, gastric erosions only occur after a prolonged period of $H$. pylori infection [31].

One of the effects of acetic acid treatment was a transient increase in neutrophils on day 5 and macrophages on days 8 and 12. Although an increase in neutrophils is described in the acute phase in human $H$. pylori infection $[16,17]$ as well as in the mouse models [13-15], the $H$. pylori strain used in the present study seems to exert a milder effect. A combined treatment of acetic acid plus $H$. pylori enhanced the influx of granulocytes and quickened the influx of macrophages. $H$. pylori is a non-invasive pathogen, yet it activates epithelial cells to produce IL-8 [32, 33] which attracts neutrophils. Furthermore, H. pylori itself synthesises and secretes chemotactic peptides, which might also contribute to the recruitment of neutrophils and macrophages $[34,35]$.

Inoculation with $H$. pylori in mice pre-treated with acetic acid resulted in colonisation of $50 \%$ of the mice on day 5. However, no difference in the number of neutrophils and macrophages was observed between colonised and non-colonised mice. It would seem that two brief exposures to the bacterial antigens were sufficient to stimulate these inflammatory cells.

The normal human stomach mucosa is devoid of organised lymphoid tissue, as it is in mice. Organised lymphoid aggregates appear in association with chronic $H$. pylori infection. The observation of regression of B-cell gastric lymphoma after eradication of $H$. pylori supports the idea that the development of organised lymphoid tissue in the stomach is antigen driven [36]. Remarkably, in several of the mice treated with $H$. pylori with or without preceding acetic acid treatment, small accumulations of $\mathrm{B}$ and $\mathrm{T}$ cells were already present in the mucosa on day 5 after the initial inoculation. No plasma cells or macrophages were observed in these accumulations, which suggests that they were primary follicles. The appearance of these early accumulations was clearly related to $H$. pylori, as they were never observed in mice that had no $H$. pylori in culture, including the untreated control mice and the mice that received acetic acid alone.

The presence of lymphoid follicles has been described in man [37] and experimental H. pylori [38] infection or infection with $H$. pylori-related species [9-12] in animals. However, those studies emphasised the chronic stages of inflammation. Lymphoid follicles with germinal centre formation are described from at least several weeks or even months after infection. An explanation for the early development of lymphoid accumulations in the present study might be the use of a cagA-expressing $H$. pylori strain. These strains are more potent inducers of an inflammatory response than strains that do not express $\operatorname{cag} A$ [14]. Lymphoid aggregates are thought to be related to a chronic gastric mucosal infection. However, the early presence of accumulations of lymphocytes rather suggests that they already play a role in the onset of the inflammatory reaction. Whereas in the present study $\mathrm{T}$ and $\mathrm{B}$ cells were found intermingled in the early lymphoid follicles, distinct $\mathrm{T}$ and $\mathrm{B}$ cell areas had developed several weeks after $H$. felis infection [39]. Whether the lymphoid aggregates in chronic gastric inflammation do resemble Peyer's patches and have a specialised follicle-associated epithelium remains to be established.

Taken together, these data illustrate that general acute inflammatory changes induced by a chemical agent such as acetic acid or by infection with $H$. pylori are different. Actual colonisation with $H$. pylori is a prerequisite for the activation of lymphocytes, suggested by the development of lymphoid follicles.

\section{References}

1. Figura N. Progress in defining the inflammatory cascade. Eur $J$ Gastrotenterol Hepatol 1995; 7: 296-302.

2. Dunn BE, Campbell GP, Pérez-Pérez GI, Blaser MJ. Purification and characterization of urease from Helicobacter pylori. $J$ Biol Chem 1990; 265: 9464-9469.

3. Eaton KA, Morgan DR, Krakowka S. Motility as a factor in the colonisation of gnotobiotic piglets by Helicobacter pylori. $J$ Med Microbiol 1992; 37: 123-127.

4. Evans DG, Evans DJ, Moulds JJ, Graham DY. N-acetylneuraminyllactose-binding fibrillar hemagglutinin of Campylobacter pylori: a putative colonization factor antigen. Infect Immun 1988; 56: 2896-2906.

5. Fauchère J-L, Blaser MJ. Adherence of Helicobacter pylori cells and their surface components to HeLa cell membranes. Microb Pathog 1990; 9: 427-439.

6. Heatley RV. Gastritis. In: Heatley RV (ed) Gastrointestinal and hepatic immunology. Cambridge, Cambridge University Press. 1994: 76-94.

7. Blaser MJ, Parsonnet J. Parasitism by the 'slow' bacterium Helicobacter pylori leads to altered gastric homeostasis and neoplasia. J Clin Invest 1994; 94: 4-8.

8. Figura N, Guglielmetti P, Rossolini A et al. Cytotoxin production by Campylobacter pylori strains isolated from patients with peptic ulcers and from patients with chronic gastritis only. $J$ Clin Microbiol 1989; 27: 225-226.

9. Lee A, Fox JG, Otto G, Murphy J. A small animal model of human Helicobacter pylori active chronic gastritis. Gastroenterology 1990; 99: 1315-1323.

10. Fox JG, Lee A, Otto G, Taylor NS, Murphy JC. Helicobacter felis gastritis in gnotobiotic rats: an animal model of Helicobacter pylori gastritis. Infect Immun 1991; 59: 785-791.

11. Fox JG, Otto G, Taylor NS, Rosenblad W, Murphy JC. Helicobacter mustelae-induced gastritis and elevated gastric $\mathrm{pH}$ in the ferret (Mustela putorius furo). Infect Immun 1991; 59: 1875-1880.

12. Mohammadi M, Redline R, Nedrud J, Czinn S. Role of the host in pathogenesis of Helicobacter-associated gastritis: $H$. felis infection of inbred and congenic mouse strains. Infect Immun 1996; 64: 238-245.

13. Cellini L, Allocati N, Angelucci D et al. Coccoid Helicobacter pylori not culturable in vitro reverts in mice. Microbiol Immunol 1994; 38: 843-850.

14. Marchetti M, Aricò B, Burroni D, Figura N, Rappuoli R Ghiara P. Development of a mouse model of Helicobacter pylori infection that mimics human disease. Science 1995; 267: $1655-1658$.

15. Lee A, O'Rourke J, Corazon de Ungria M, Robertson B, Daskalopoulos G, Dixon MF. A standardized mouse model of Helicobacter pylori infection: introducing the Sydney Strain. 
Gastroenterology 1997; 112: 1386-1397.

16. Marshall BJ, Armstrong JA, McGechie DB, Glancy RJ. Attempt to fulfil Koch's postulates for pyloric campylobacter. Med J Aust 1985; 142: 436-439

17. Morris A, Nicholson G. Ingestion of Campvlobacter pyloridis causes gastritis and raised fasting gastric $\mathrm{pH}$. Am J Gastroenterol 1987; 82: 192-199.

18. Taha AS, Sturrock RT, Russell RI. Mucosal erosions in longterm non-steroidal anti-inflammatory drug users: predisposition to ulceration and relation to Helicobacter pylori. Gut 1995; 36: 334-336.

19. Yokota K, Kurebayashi Y, Takayama Y et al. Colonization of Helicobacter pylori in the gastric mucosa of Mongolian gerbils. Microbiol Immunol 1991; 35: 475-480.

20. Namavar F, Roosendaal R, Kuipers EJ et al. Presence of Helicobacter pylori in the oral cavity, oesophagus, stomach and faeces of patients with gastritic. Eur J Clin Microbiol Infect Dis 1995; 14: 234-237.

21. Ausubel FM, Brent R, Kingston RE et al. In: Current protocols in molecular biology. New York, Greene Publishing Associates and Wiley-Interscience. 1987.

22. Tummuru MKR, Cover TL, Blaser MJ. Cloning and expression of a high-molecular-mass major antigen of Helicobacter pylori: evidence of linkage to cytotoxin production. Infect Immun 1993; 61: $1799-1809$.

23. Dent JC, McNulty CAM. Evaluation of a new selective medium for Campylobacter pylori. Eur J Clin Microbiol Infect Dis 1988; 7: $555-568$

24. Graham RC, Karnovsky MT. The early stages of absorption of injected horseradish peroxidase in the proximal tubulus of mouse kidney: ultrastructural cytochemistry by a new technique. J Histochem Cytochem 1966; 14: 291-302.

25. Coffman RL. Surface antigen expression and immunoglobulin gene rearrangement during mouse pre- $\mathrm{B}$ cell development. Immunol Rev 1982; 69: 5-23.

26. Ledbetter JA, Herzenberg LA. Xenogeneic monoclonal antibodies to mouse lymphoid differentiation antigens. Immunol Rev 1979; 47: 63-90.

27. Kraal G, Rep M, Janse M. Macrophages in $T$ and B cell compartments and other tissue macrophages recognized by monoclonal antibody MOMA-2: an immunohistochemical study. Scand J Immunol 1987; 26: 653-661.

28. Lemke H, Hämmerling GJ, Hämmerling U. Fine specificity analysis with monoclonal antibodies of antigens controlled by the major histocompatibility complex and by the Qa/TL region in mice. Immunol Rev 1979; 47: 175-206.

29. Kraal G, Breel M, Janse M, Bruin G. Langerhans' cells, veiled cells, and interdigitating cells in the mouse recognized by a monoclonal antibody. $J$ Exp Med 1986; 163: 981-997.

30. Yamada T, Marshall S, Specian RD, Grisham MB. A comparative analysis of two models of colitis in rats. Gastroenterology 1992; 102: 1524-1534.

31. Stolte M, Eidt S. Lymphoid follicles in antral mucosa: immune response to Campylobacter pylori? J Clin Pathol 1989; 42: $1269-1271$

32. Sharma SA, Tummuru MKR, Miller GG, Blaser MJ. Interleukin-8 response of gastric epithelial cell lines to Helicobacter pylori stimulation in vitro. Infect Immun 1995; 63: 1681-1687.

33. Crabtree JE, Covacci A, Farmery SM et al. Helicobacter pylori induced interleukin-8 expression in gastric epithelial cells is associated with CagA positive phenotype. J Clin Pathol 1995; 48: $41-45$.

34. Mooney C, Keenan J, Munster D et al. Neutrophil activation by Helicobacter pylori. Gut 1991; 32: 853-857.

35. Neilsen H, Andersen LP. Chemotactic activity of Helicobacter pylori sonicate for human polymorphonuclear leucocytes and monocytes. Gut 1992; 33: 738-742.

36. Wotherspoon $\mathrm{AC}$, Ortiz-Hidalgo $\mathrm{C}$, Falzon $\mathrm{MR}$, Isaacson $\mathrm{PG}$. Helicobacter pylori-associated gastritis and primary B-cell lymphoma. Lancet 1991; 338: 1175-1176.

37. Eidt S, Stolte M. Prevalence of lymphoid follicles and aggregates in Helicobacter pylori gastritis in antral and body mucosa. J Clin Pathol 1993; 46: 832-835.

38. Krakowka S, Morgan Dr, Kraft WG, Lennk RD. Establishment of gastric Campylobacter pylori infection in the neonatal gnotobiotic piglet. Infect Immun 1987; 55: 2789-2796.

39. Pappo J, Thomas WD, Kabok Z, Taylor NS, Murphy JC, Fox JG. Effect of oral immunization with recombinant urease on murine Helicobacter felis gastritis. Infect Immun 1995; 63 $1246-1252$ 